NASA/TM-1998-206636

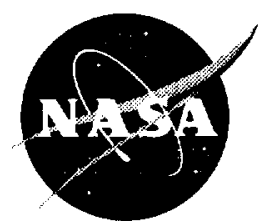

\title{
Propulsion System for Very High Altitude Subsonic Unmanned Aircraft
}

David J. Bents, Ted Mockler, and Jaime Maldonado

Lewis Research Center, Cleveland, Ohio

James L. Harp, Jr. and Joseph F. King

ThermoMechanical Systems Inc., Canoga Park, California

Paul C. Schmitz

Power Computing Solutions Inc., Avon, Ohio

Prepared for the

Aerospace Power Systems ' 98

sponsored by the Society of Automotive Engineers

Williamsburg, Virginia, April 21-23, 1998

National Aeronautics and

Space Administration

Lewis Research Center 
Available from

NASA Center for Aerospace Information 800 Elkridge Landing Road

Linthicum Heights, MD 21090-2934

Price Code: A03
National Technical Information Service 5287 Port Royal Road Springfield, VA 22100 Price Code: A03 


\title{
Propulsion System for Very High Altitude Subsonic Unmanned Aircraft
}

\author{
David J. Bents, Ted Mockler, and Jaime Maldonado \\ NASA Lewis Research Center \\ James L. Harp Jr. and Joseph F. King \\ ThermoMechanical Systems Inc. \\ Paul C. Schmitz \\ Power Computing Solutions Inc.
}

\begin{abstract}
This paper explains why a spark ignited gasoline engine, intake pressurized with three cascaded stages of turbocharging, was selected to power NASA's contemplated next generation of high altitude atmospheric science aircraft. Beginning with the most urgent science needs (the atmospheric sampling mission) and tracing through the mission requirements which dictate the unique flight regime in which this aircraft has to operate (subsonic flight @ $>80 \mathrm{kft}$ ) we briefly explore the physical problems and constraints, the available technology options and the cost drivers associated with developing a viable propulsion system for this highly specialized aircraft. The paper presents the two available options (the turbojet and the turbocharged spark ignited engine) which are discussed and compared in the context of the flight regime. We then show how the unique nature of the sampling mission, coupled with the economic considerations pursuant to aero engine development, point to the spark ignited engine as the only cost effective solution available. Surprisingly, this solution compares favorably with the turbojet in the flight regime of interest. Finally, some remarks are made about NASA's present state of development, and future plans to flight demonstrate the three stage turbocharged powerplant.
\end{abstract}

\section{INTRODUCTION}

Because of the increasing influence of man-made pollutants and their potential impact on Earth's atmosphere, the science community is expending considerable effort to gain a better understanding of its detailed chemistry and dynamics. Much of the work involves the development of more sophisticated computer models of the atmosphere. These are validated through correlations with observed data, which includes both remote sensing and in situ measurements. At present, the highest priority measurements are in situ measurements at altitudes above $73 \mathrm{kft}$ to over $80 \mathrm{kft}$, especially within $12^{\circ}$ of the Equator. The in situ measurements are hardest to obtain since they involve physical samples taken by airborne instruments. Aircraft are the preferred instrument platform because of the length and directedness of the flightpath, which allows large numbers of samples to be obtained at specified locations in the atmosphere, at the specific times dictated by science opportunity.

The most urgent need is for an aircraft that can fly long distances at altitudes significantly above $80 \mathrm{kft}$. The aircraft presently used for sampling, even the high altitude ER-2, are not capable of flying much higher than $73 \mathrm{kft}$. While balloon borne instruments can reach altitudes as high as $130 \mathrm{kft}$, the undirected nature of balloon flight limits the geographic coverage and spatial resolution that is needed (the coverage achieved by a single airplane flight is the equivalent of 10-100 simultaneous balloon flights). There are a limited number of supersonic aircraft capable of flying over $80 \mathrm{kft}$, but these aircraft achieve high altitude by flying supersonically. The aerodynamic heating and shock associated with supersonic flight cause changes to the air sample which negate the measurements being made. The airplane which performs the sampling mission must be subsonic. This presents a contradiction-the most straightforward way to achieve high altitudes is to fly fast, but this airplane must fly high and slow-a very difficult thing to achieve. Because of the exponential lapse of air density with altitude, a subsonic aircraft flying at $80 \mathrm{kft}$ altitudes cannot generate much lift (see Fig. 1). Even at reasonably high speeds $(M=0.5)$ the dynamic pressure available limits wing loadings to only 7 to 12 psf; more like a sailplane than a powered aircraft.

\section{THE PROPULSION CHALLENGE}

It is widely acknowledged that the propulsion system is the most difficult technical challenge. Whether it is manned or unmanned, an aircraft designed to fly subsonically $>80 \mathrm{kft}$ for $>4 \mathrm{hrs}$ will 
require a propulsion system that is quite different from existing systems. Because of range and flight duration, air breathing propulsion is required. In this flight regime, however, air breathing propulsion is difficult to achieve. The difficulty arises from the exponential lapse of air density and pressure with altitude. At $80 \mathrm{kft}$ the ambient air density and pressure are about 1/30th of sea level values. As Fig. 1 shows, subsonic forward speeds do not generate much inlet pressurization (at $80 \mathrm{kft}, \mathrm{M}=0.5$, less than $10 \mathrm{psf}$ is available). Therefore, turbomachinery is needed to supply most of the intake pressurization required to compress ambient air into a powerplant working fluid of reasonable density.

To pressurize the intake to 1 atm at $80 \mathrm{kft}$, an overall pressure ratio (OPR) better than $36: 1$ is required. Several turbomachinery stages are needed for intake pressurization. For example, at least 3 centrifugal compressor stages are required to provide an OPR of 30 to 40; more if an axial compressor is used. Because of low inlet density, the turbomachinery is large in size, especially the first stage. Volume flow (corrected flow) requirements increase with altitude, which translates to larger turbomachinery diameters. Pressure ratio requirements also increase with altitude, which translates to more turbomachinery stages. Since power is proportional to airflow for any air breathing engine, the machinery size required to process airflow for a given rated power will grow with altitude as OPR and corrected flow are increased. Figure 2 illustrates how machine diameter and length must change as OPR and corrected flow are increased to compensate for altitude. Two turbo-machines are shown. One is an axial flow unit typical of a turbojet engine, pressurizing a 40 psia combustor flowing a constant $100 \mathrm{lbm} / \mathrm{sec}$. The other is a centrifugal unit common to reciprocating engine turbochargers, maintaining a constant 30 in $\mathrm{HgA}$ manifold pressure and flowing $0.2 \mathrm{lbm} / \mathrm{sec}$. Both machines are compressing from altitude ambient conditions at the inlet (US Std. Atmosphere). Interstage cooling is assumed for both, and consistent tip speed limits and inlet flow velocities are observed for each machine type. Note how machine dimensions must increase as the inlet conditions are changed from sea level to $90,000 \mathrm{ft}$. For either unit, length increases more than 5 times while diameter increases more than sevenfold. Weight is proportional to the cube of linear dimensions.

The atmospheric density lapse causes the need for very large heat exchangers. The density lapse from sea level to $80 \mathrm{kft}$ produces a five fold decrease in Reynolds number (Re) and more than tenfold decrease in convective heat transfer. Heat exchanger sizing is driven upwards by three factors: (a) reduced convective heat transfer available, (b) the lower density ambient air has less heat capacity, and (c) the need for more heat rejection, due to the increased compression heat loads associated with higher OPR's For example, Fig. 3 shows how the weight and frontal area of a typical aircraft engine coolant heat exchanger must increase to reject the same heat load at altitude versus a sea level unit (including the effects of reduced air temperature with altitude).

Flying subsonically in low density air also creates the requirement for larger thruster "capture area" or "actuator disk" areas in order to achieve reasonable propulsive efficiencies that are needed to reduce fuel consumption and provide range. Figure 4 shows the relationship between the minimum thruster "capture area" needed to maintain $\mathbf{1 0 0} \mathrm{lbf}$ thrust versus altitude (US Std. Atmosphere), for a given propulsive efficiency. Two representative airspeeds are illustrated. Mach 0.8 represents the approximate upper speed limit for a subsonic jet aircraft, while Mach 0.4 represents a slower aircraft speed that reduces fuel burn. At $80 \mathrm{kft}$ and $M=0.8$, a 50 percent propulsive efficiency requires at least $1 \mathrm{tt}^{2}$ capture area, which is equivalent to the nozzle exit of a small turbojet. If capture area can be raised to $8 \mathrm{ft}^{2}$, however (equivalent to a turbofan engine), propulsive efficiency improves to 90 pct. At the slower speed of $M=0.4$, the same $8 \mathrm{ft}^{2}$ capture area would produce only 70 pct efficiency-to regain 90 pct efficiency the capture area has to be increased to at least $30 \mathrm{ft}^{2}$ (i.e. a propeller-note that actual capture areas will be somewhat larger than this idealized minimum). Subsonic flight at altitudes $>80 \mathrm{kft}$ will favor thrusters with relatively large actuator areas (i.e. a propeller driven aircraft), and the actuator size (i.e. propeller diameter) will be 2 to 3 times larger than what is common for a conventional aircraft.

Because of the increased size and weight of the air handling, thermal management and thrust delivery components, a propulsion system designed for high altitudes is significantly larger and heavier than its low altitude counterpart. Further complicating matters, the high altitude aircraft will need more power to stay aloft because of the faster flight speeds necessary (to maintain dynamic pressure and support its weight in low density air). The propulsion system grows in both rating and in specific weight, which tends to claim greater and greater fractions of the airplane's gross weight. This of course runs counter to the airplane's ability to carry the weight.

\section{PROPULSION SYSTEM OPTIONS}

The weight penalty associated with air handling and thermal management becomes a major discriminator when chosing propulsion for the high altitude aircraft. There are two powerplant candidates to consider: turbine engines (i.e. a turbojet) and turbocharged reciprocating engines. The turbojet 
engine would be associated with a relatively high speed $(0.7<M<0.8)$ aircraft of conventional size with wing loadings in the range of sailplanes and light aircraft (15 to $25 \mathrm{psf}$ ); the turbocharged reciprocating engine would power a very large very lightly constructed propeller driven aircraft $(M=0.4$, wing loading 4 to $7 \mathrm{psf}$ ) that maximizes range and endurance. Figure 5 shows a represent-ative turbine engine (turbojet); Fig. 6 shows a representative turbocharged reciprocating engine. Both are shown configured for the $>80 \mathrm{kft}$ flight regime. As designed for $>80 \mathrm{kft}$ flight, the distinctions between the two become somewhat blurred since the turbocharged reciprocating engine could be considered as a variant of the turbine engine, where a reciprocating engine has replaced the combustor core. Both require large amounts of air, but there are major differences between them concerning airflow usage. The turbine engine ingests large amounts of air whose heat of compression is retained in the cycle, while the turbocharged reciprocating engine compresses only a small fraction of the air it ingests, and uses the remainder only for heat rejection. Heat rejection includes what is lost to engine oil and coolant, plus the induction air stream's heat of compression. The turbine engine rejects almost all of its waste heat in the cycle exhaust (which is used for for thrust), while the turbocharged reciprocating engine rejects a significant fraction of its waste heat to the engine oil and coolant. Large HX's are required to remove waste heat from engine coolant and oil, and compression heating from the induction air (but the cooling air flowing through them does not have to be mechanically compressed).

At low altitudes, the turbine engine can generate 2 to 5 times higher power density than the reciprocating engine as long as inlet air mass flow is adequate. Mass flow is easily obtained at low altitudes where air densities are high, and is achievable at higher altitudes by flying at faster speeds using inlet precompression. Historically the turbine engine was the key to high altitude flight, since it was the first powerplant with high enough specific power to push level flight into the supersonic range. The turbine engine's higher fuel consumption, 1.5 to 2 times that of the reciprocating engine, is not a disadvantage for most aircraft applications because of the higher specific power.

The acknowledged altitude records for subsonic flight, (shown in Table I), are dominated by turbine powered aircraft. The highest is held by the Viet Nam era AQM91 Compass Arrow spyplane, which achieved better than $80 \mathrm{kft}$ more than 25 years ago [1]. Powered by a special design turbojet engine (shown in Fig. 7) this aircraft achieved its record altitude flying at $M=0.83$, a speed which was just enough to give the inlet precompression needed to keep its combustor lit. The turbine engine exhibits a specific power that varies roughly proportional to ingested air density since machine size is fixed. As density drops off at higher altitudes, the machine ingests less air mass, resulting in reduced power and reduced thrust. Combustor pressure is correspondingly reduced; eventually to the point where combustion of hydrocarbon fuel can no longer be supported. Figure 7 shows the J97's thrust lapse curve, whose behavior is typical of all turbine engines. As an example, the Compass Arrow's $\mathrm{J} 97$ turbojet which was capable of $>4,000 \mathrm{lbf}$ thrust at sea level, would produce only $184 \mathrm{lbf}$ at $80 \mathrm{kft}(\mathrm{M}=0.85)$ and is operating on the verge of flameout.

The high altitude $\mathrm{J} 97$ engine never went into production because Compass Arrow was ultimately canceled. There remain twenty-four (24) J-97 preproduction prototype units (the engine was never fully qualified) which were surplussed to NASA following the Air Force's decision not to pursue system acquisition. These are in storage at NASA Ames Research Center.

It would be possible to design a new turbojet engine for flying beyond the J97's $\sim 80 \mathrm{kft}$ limits using present day materials and turbine technology. This engine would incorporate a high pressure ratio compressor (25 to 35 to 1 ) with wide chord first stage blades (to minimize Reynolds number effects) and a stabilized pilot flame combustor (using a secondary fuel such as hydrogen) to prevent flameout at high altitudes. Figure 8 shows the preliminary concept layout for such an engine. Compared to the J97, this new engine has larger flow areas (larger diameter), more turbo-machinery stages, higher overall pressure ratio, higher flameout altitudes, and more thrust. As Fig. 8 shows, this engine would be capable of altitudes up to $\sim 90 \mathrm{kft}$ at subsonic speeds. Because these adaptations for the $>80 \mathrm{kft}$ flight regime make it larger and heavier than the J97, it would not be competitive with other jet engines for most missions.

Unfortunately, costs preclude development of a new turbine engine. Compass Arrow's J97, which was a Cold War scaling/adaptation from the larger GE-1, cost approximately $\$ 60 \mathrm{M}$ to develop during the mid 1960 's. This is a sum roughly equal to $\$ 300 \mathrm{M}$ today. The market anticipated for atmospheric science aircraft consists of no more than a dozen units. As a result, the only turbine engine that would be available for a new atmospheric science aircraft would be a $\mathrm{J} 97$ unit rebuilt from the remaining inventory of prototype hardware that never became a manufacturer supported product. 
PROPULSION SYSTEM SELECTION FOR ATMOSPHERIC SCIENCE AIRCRAFT

These considerations leave the turbocharged reciprocating engine as the only remaining candidate, since it is the only low cost candidate. The turbocharged engine is low cost, because of the existing technology base of mass produced automotive and general aviation hardware that can be adapted to build such an engine. The technology is widely available and well supported. Recent trends in automobile manufacture to reduce weight (improve fuel economy) have rendered this technology base more applicable to aircraft propulsion, to the extent that many general aviation home builders have developed automotive powerplant conversions that are weight competitive with certified aero engine installations. There is a marketplace for turbocharged engines that already includes a number of small business developers who mainly modify and assemble hardware manufactured by others (for auto racing, experimental and homebuilt aircraft etc), some of whom might find a niche participating in the development/manufacture/service/ support of specialized turbocharged powerplants for high altitude unmanned aircraft (potentially a profitable niche for commercial HALE platforms, a very small niche for atmospheric science aircraft).

The turbocharged powerplant is cheaper because it is built up from mass produced components from other applications which have been adapted. The development costs are low because of the considerable design heritage that survives from pre-jet age aviation development, and experience gained from earlier attempts to develop turbocharged high altitude powerplants. Several multiple stage turbocharged systems have already been demonstrated either in high altitude flight or altitude test chambers. Table II (previous high altitude turbocharged IC engines) summarizes the flight capability/performance that has been achieved to date.

The turbocharged reciprocating engine is technically quite competitive with the turbine engine at high altitudes. Although the power density of a turbine engine is higher than the reciprocating engine at normal altitudes, the reciprocating engine begins to compare favorably with turbine engine at altitudes above $80 \mathrm{kft}$, especially at the lower speeds where inlet precompression is not available. While it must be augmented with multiple stages of turbocharging and intercooling for atmosphere pressure/density compensation, the reciprocating engine's weight growth with altitude is not as rapid as the pure turbine engine's; mainly because the turbomachinery needed to raise OPR is confined to the induction air, which is less than $1 / 10$ th the overall air consumption.
The highest altitude potential accrues to the spark ignited gasoline engine since it burns a nearly stochiometric fuel air mixture, thus maximizing induction air utilization. Furthermore, its exhaust gases are hot enough (1400 to $1600{ }^{\circ} \mathrm{F}$ ) to yield excess enthalpy which is needed to provide the turbocharger compressor work. Intake pressurization is accomplished by multiple stage units arranged in cascade, so that as altitude increases and ambient pressure decreases, the increasing pressure ratio across the turbine increases enthalpy extraction, roughly balancing the increased compressor loading.

The power density of the turbocharged reciprocating engine is limited by core engine detonation limits not the turbomachinery, so the resulting curve of performance with altitude (shown in Fig. 9) is "flat" extending from sea level to critical altitude where the turbo-machinery was sized (to deliver rated intake airflow and pressure). Above critical altitude the turbo-machinery can no longer sustain these airflows, so the performance curve exhibits a lapse behavior similar to the turbojet. As a design parameter, critical altitude should approximately coincide with the aircraft's design altitude and not exceed it, since the high altitude power generation capability so dearly paid for in propulsion weight is wasted beyond that point.

Figure 10 shows specific air consumption of five air breathing engine types. Of these, the spark ignited gasoline engine has the lowest specific air consumption. Owing to its near stochiometric combustion, it utilizes all the air which is processed-a major advantage where air processing makes up most of the powerplant. In addition, the turbocharged reciprocating engine retains lower fuel consumption. Table III compares the specific weight and thrust specific fuel consumption of representative turbojet and turbocharged powerplant installations at 80 and $90 \mathrm{kft}$. Specific weights apply to the entire propulsion unit (including drivetrains, propellers, heat exchangers, etc.) and flight speeds are chosen to provide each powerplant with its inherent competitive advantage. Comparison shows that at $80 \mathrm{kft}$ the turbocharged propeller unit will be slightly heavier per lbf thrust than the turbojet, but it will have lower thrust specific fuel consumption (TSFC). If the comparsion is repeated at $90 \mathrm{kft}$, the turbocharged unit is somewhat lighter than the turbojet per Ibf thrust and has lower TSFC. These same trends were also observed when turbocharged reciprocating engines were compared with specialized turboprop units designed for $90 \mathrm{kft}$ [2].

These performance advantages may be exploited to a limited extent, but due to the increasing size and weight of ancillaries required to maintain altitude performance, the powerplant eventually becomes too heavy to be supported by the wing loading available. 
In order to illustrate how size and weight are increasing, Table IV presents a weight breakdown for a triply turbocharged $>80 \mathrm{kft}$ altitude powerplant based on a Rotax engine core. This breakdown should be compared to an equivalent weight breakdown for the single stage turbocharged Rotax engine that is designed for $15 \mathrm{kft}$. NASA airframe/ propulsion studies [3] indicate that for subsonic airframes using modern composite materials, the maximum altitude potential for subsonic flight will be limited by powerplant growth to about $90 \mathrm{kft}$ (see Fig. 11, the no fly zone).

Reliability of the turbocharged reciprocating engine will be lower than a turbine engine since it is physically more complicated. Operational reliability of a system consisting of so many interconnected elements is a significant issue. Historically, turbocharged piston aero engines have required regular maintainance over operating intervals measured in tens of hours, and complete overhauls after hundreds of hours operation. This contrasts with modern turbine engines which require maintainance after hundreds of hours of operation, and thousands of hours between overhauls. A powerplant developed for the atmospheric science mission will be very limited production; so reliability issues associated with inherent system characteristics are more likely to be overshadowed by the teething problems associated with few-of-a-kind systems. Since a remotely piloted aircraft gives the operator only limited ability to detect problems in flight and even less ability to respond to them, low reliability means a higher likelihood of loss for both mission and aircraft. These risks may be tolerable if human operators are no longer in harm's way.

\section{CURRENT PROPULSION DEVELOPMENTS}

Since the ERAST program was inaugurated in 1994. NASA has pursued development of a three stage turbocharged gasoline engine as the propulsion option for its very high altitude atmospheric science aircraft. NASA is currently developing a subscale prototype propulsion unit intended for an unmanned flight demonstration known as Alliance One. Unlike the German Grob/DLR "Strato 2C" atmospheric science aircraft ([4 and 5] see Table I), Alliance One is intended to be a technology demonstrator addressing $>80 \mathrm{kft}$ subsonic flight, not a mission demonstration.

Present development is focussed on a three stage turbocharged powerplant using the four cylinder Rotax 912 engine core. Popular with remotely piloted aircraft (RPA) and "homebuilt" experimental aircraft developers, this engine is in volume production and has factory technical support available. Its versatile design accommodates both air and liquid cooling such that it can be all liquid cooled for high altitudes or fully enclosed installations. The three stage turbocharger system is being developed by ThermoMechanical Systems (TMS) of Canoga Park, California, the original developers of the TEAL RAIN three stage turbocharged engine ([6], see Table II). To save money, much of the original TEAL RAIN hardware has been re-utilized. Figure 12 is a photograph of the triply turbocharged Rotax engine in the TMS chamber, Fig. 13 shows the power levels at various altitudes which have been demonstrated by this engine to date (exceeding the original program goals). These demonstrations are an important milestone, but will not lead immediately to a high altitude flight since it is only a brassboard demonstration of critical hardware, not the entire propulsion unit which has yet to be developed. So far, rated horsepower has been produced in a dynamometer altitude chamber under quasi-steady state conditions, controlled by hand. Critical subsystems still missing from the demonstration include thermal management, transmission, drivetrain and propeller, powerplant and propulsion unit automatic controls.

Work is already underway on many of these subsystems, with thermal management receiving the most attention. High altitude low Reynold number heat exchangers are presently being researched by NASA Lewis and a consortium of four heat exchanger manufacturers led by the Ohio State University Research Foundation. Nacelle and inlet aerodynamics are being researched by groups at NASA and Old Dominion University. Definition of the propeller has also begun, led by Alliance partner Aurora Flight Sciences. Drivetrain and propeller development is considered a unique challenge since the propeller, despite its being a variable pitch unit, will be subject to greater than 2:1 speed variation when traversing from sea level to $>80 \mathrm{kft}$. Aurora Flight Sciences, Inc. is developing a two speed transmission and drivetrain to complete the propulsion unit. Automatic controls development, a natural part of the integration process, is proceeding with turbocharged engine/heat exchanger integration. TMS has developed automatic powerplant controls for the throttle, intercoolers and turbocharger wastegate using the engine control computer's expansion capability. The control actuators themselves are developed by General Atomics. Aurora is developing a supervisory propulsion control system that will interface the powerplant, transmission and propeller with the aircraft flight controls.

After all this propulsion hardware has been developed and extensively ground tested to ensure it "works as advertised," it will be integrated into the Alliance One airframe leading to the ultimate objective of ERAST propulsion development: flight demonstration of affordable technology to meet the science mission requirements. 


\section{SUMMARY AND CONCLUSIONS}

The atmospheric science mission requirements dictate a very high altitude subsonic aircraft. This aircraft requires a propulsion system which presently does not exist, but can be developed from air breathing engine technology. There are two candidates: turbojets and propeller/turbocharged spark ignited reciprocating engines. Although the turbojet would appear to be the leading candidate, as it was for high altitude missions historically, there is no turbine engine available for the atmospheric science flight regime, and it is unlikely that a suitable turbine engine will ever be developed, due to the limited marketplace associated with atmospheric science applications.

Therefore, the propeller/turbocharged spark ignited gasoline engine is the only option available. Fortunately, the spark ignited powerplant enjoys some subtle physical advantages over the turbojet for high alitude low speed flight, arising from its nearstochiometric combustion. Its low specific air consumption reduces the amount and weight of turbomachinery required to generate power at $>80 \mathrm{kft}$, which apparently results in lower weight and lower TSFC than a turbojet in this flight regime, despite the large heat exchangers.

Borrowing from the technology heritage of automotive and homebuiltexperimental aircraft powerplants and Cold War era high altitude military reconaissance development programs, NASA is now developing a variant of the 3 stage turbocharged powerplant for application to the atmospheric science mission. To date, only the engine and turbocharger performance has been demonstrated, under carefully controlled conditions. Work is ongoing to develop the remaining required components, and build the demonstration hardware into a propulsion system which will lead to an aircraft technology flight feasibility demonstration.

\section{REFERENCES}

1. W. Wagner and W. Sloan, "Fireflies and Other UAV's," Teledyne Ryan Aeronautical Co., San Diego CA, June 1993.

2. J.L.Bettner, C.S. Blandford and B.J. Rezy, "Propulsion Assessment for Very High Altitude UAV Under ERAST," NASA Report 95N27866, Allison Engine Company, June 1995.

3. Report of the Environmental Research Aircraft and Sensor Technology (ERAST) Program Leadership Team, "A Review of Remotely Piloted Aircraft (RPA) Technology Required for High Altitude Civil Science Missions," National Aeronautics and Space Administration, Washington DC, March 1996.

4. H. Tonksotter, "The Strato $2 \mathrm{C}$ Propulsion System; A Low Cost Approach for a High Altitude Long Endurance Aircraft," IndustrieanlagenBetriebsgesellschaft mbH, March 1994.

5. Anon, "Strato 2C Technical Description", Deutsche Forschungsanstalt fur Luft und Raumfarht (DLR) , November 1993.

6. J. Harp, "Turbocharger System Development and Propulsion System Testing:, TMS Report No. SR-36, prepared for Developmental Sciences Inc. under Contract No. DSI-80-TR-SC-05-A, ThermoMechanical Systems Inc., Canoga Park CA, May 1982 (declassified Mar 1994). 
TABLE I.-PREVIOUS HIGH ALTITUDE SUBSONIC AIRCRAFT

\begin{tabular}{|c|c|c|c|c|}
\hline Aircraft designation & $\begin{array}{c}\text { Original purpose, and } \\
\text { year flown }\end{array}$ & $\begin{array}{l}\text { Altitude } \\
\text { record }\end{array}$ & $\begin{array}{l}\text { Propulsion system } \\
\text { used }\end{array}$ & $\begin{array}{c}\text { Science platform } \\
\text { availability }\end{array}$ \\
\hline WB-57 & $\begin{array}{c}\text { High altitude strategic } \\
\text { bomber }(1949)\end{array}$ & $\begin{array}{l}65,876 \mathrm{ft} \\
8 / 29 / 55\end{array}$ & $\begin{array}{c}\text { Bristol } \\
\text { "Olympus" turbojet }\end{array}$ & $\begin{array}{l}\text { NCAR atmospheric } \\
\text { science }\end{array}$ \\
\hline ER-2 & $\begin{array}{c}\text { High altitude } \\
\text { reconnaissance (1955) }\end{array}$ & $\begin{array}{c}73,200 \mathrm{ft} \\
8 / 4 / 95\end{array}$ & $\begin{array}{l}\text { GE-F118 } \\
\text { turbofan }\end{array}$ & $\begin{array}{c}\text { NASA atmospheric } \\
\text { science }\end{array}$ \\
\hline $\begin{array}{c}\text { AQM91M } \\
\text { Compass Arrow }\end{array}$ & $\begin{array}{c}\text { High altitude } \\
\text { reconnaissance (1969) }\end{array}$ & $\begin{array}{l}>81,000 \mathrm{ft} \\
\text { Sept. } 1969\end{array}$ & $\begin{array}{c}\text { GE-J97-3 } \\
\text { turbojet } \\
\end{array}$ & $\begin{array}{l}\text { military only, no } \\
\text { longer exists }\end{array}$ \\
\hline Grob Egrett & $\begin{array}{l}\text { High altitude science } \\
\text { aircraft (1988) }\end{array}$ & $\begin{array}{c}53,055 \mathrm{ft} \\
9 / 1 / 88\end{array}$ & $\begin{array}{l}\text { Garrett TPE331 } \\
\text { turboprop }\end{array}$ & $\begin{array}{l}\text { DoE atmospheric } \\
\text { science }\end{array}$ \\
\hline Boeing Condor & $\begin{array}{l}\text { High altitude ELINT } \\
\text { reconnaissance (1989) }\end{array}$ & $\begin{array}{l}67,028 \mathrm{ft} \\
2 / 15 / 89\end{array}$ & $\begin{array}{l}2 \text { stage turbocharged } \\
\text { spark ignition engine }\end{array}$ & $\begin{array}{l}\text { military only, no } \\
\text { longer exists }\end{array}$ \\
\hline Grob Strato $2 \mathrm{C}$ & $\begin{array}{c}\text { Atmospheric science } \\
\text { (1995) }\end{array}$ & $\begin{array}{c}60,867 \mathrm{ft} \\
8 / 4 / 95\end{array}$ & $\begin{array}{l}3 \text { stage turbocharged } \\
\text { spark ignition engine }\end{array}$ & $\begin{array}{l}\text { DLA (Germany) } \\
\text { program was } \\
\text { canceled }\end{array}$ \\
\hline
\end{tabular}

TABLE II.-TURBOCHARGED RECIPROCATING ENGINES

\begin{tabular}{|c|c|c|c|c|c|c|}
\hline & Developer & $\begin{array}{c}\text { Core engine } \\
\text { used }\end{array}$ & $\begin{array}{c}\text { Number of } \\
\text { stages/turbo } \\
\text { manufactor }\end{array}$ & $\begin{array}{l}\text { Rated hp demo } \\
\text { at rated alt. }\end{array}$ & $\begin{array}{l}\text { Highest recorded } \\
\text { ground test } \\
\text { performance } \\
\end{array}$ & $\begin{array}{l}\text { Highest altitude } \\
\text { achieved in flight }\end{array}$ \\
\hline TEAL RAIN & $\begin{array}{l}\text { Thermo } \\
\text { Mechanical } \\
\text { Systems } \\
\text { (TMS) }\end{array}$ & $\begin{array}{c}3 \text { cylinder } \\
\text { Drake } 36.6 \text { cid }\end{array}$ & 3 stages/TMS & $\begin{array}{c}70 \mathrm{hp} \\
\text { at } 65 \mathrm{kft} \\
\text { Feb. } 1982\end{array}$ & $\begin{array}{c}47 \mathrm{hp} \\
\text { at } 90 \mathrm{kft} \\
\text { Mar. } 1982\end{array}$ & $\begin{array}{c}\text { ground demo } \\
\text { only }\end{array}$ \\
\hline Condor & $\begin{array}{l}\text { Boeing } \\
\text { Teledyne } \\
\text { Continential } \\
\text { Motors }\end{array}$ & $\begin{array}{l}6 \text { cylinder } \\
\text { Continental } \\
350 \text { cid }\end{array}$ & $\begin{array}{l}2 \text { stages/ } \\
\text { Teledyne } \\
\text { continental }\end{array}$ & $\begin{array}{l}182 \mathrm{hp} \\
\text { at } 67 \mathrm{kft} \\
\text { Feb. } 1989\end{array}$ & $\begin{array}{l}\text { data not } \\
\text { available }\end{array}$ & $\begin{array}{l}67,028 \mathrm{ft} \\
\text { Feb. } 1989\end{array}$ \\
\hline Strato $2 \bar{C}$ & $\begin{array}{c}\text { Grob/lABG/ } \\
\text { DLR }\end{array}$ & $\begin{array}{c}6 \text { cylinder } \\
\text { Continential } \\
550 \mathrm{cid} \\
\end{array}$ & $\begin{array}{c}3 \text { stages/ } \\
\text { IABG/P+W/ } \\
\text { Garrett }\end{array}$ & $\begin{array}{c}400 \mathrm{hp} \\
\text { at } 78 \mathrm{kft} \\
\text { Dec. } 1994\end{array}$ & $\begin{array}{c}308 \mathrm{hp} \\
\text { at } 82 \mathrm{kft} \\
\text { Apr. } 1995 \\
\end{array}$ & $\begin{array}{l}60,876 \mathrm{ft} \\
\text { Aug. } 1995\end{array}$ \\
\hline Raptor D2 & $\begin{array}{c}\text { Scaled } \\
\text { Composites/ } \\
\text { TMS }\end{array}$ & $\begin{array}{c}4 \text { cylinder } \\
\text { ROTAX } 74 \text { cid }\end{array}$ & 2 stages/TMS & $\begin{array}{c}103 \mathrm{hp} \\
\text { at } 54 \mathrm{ktt} \\
\text { Jan. } 1996\end{array}$ & $\begin{array}{c}47 \mathrm{hp} \\
\text { at } 70 \mathrm{kft} \\
\text { Jan. } 1996\end{array}$ & Not flown yet \\
\hline Perseus $\mathrm{B} / \mathrm{Th}$ heseus & $\begin{array}{l}\text { Aurora Flight } \\
\text { Sciences }\end{array}$ & $\begin{array}{c}4 \text { cylinder } \\
\text { ROTAX } 74 \text { cid }\end{array}$ & 3 stages/Garrett & $\begin{array}{c}73 \mathrm{hp} \\
\text { at } 59 \mathrm{kft} \\
\text { May } 1994\end{array}$ & $\begin{array}{c}73 \mathrm{hp} \\
\text { at } 59 \mathrm{ktt} \\
\text { May } 1994\end{array}$ & $\begin{array}{l}20,000 \mathrm{ft} \\
\text { Mar. } 1996\end{array}$ \\
\hline Altus & $\begin{array}{c}\text { General } \\
\text { Atomics } \\
\text { AeroSystems } \\
\text { TTMS }\end{array}$ & $\begin{array}{c}4 \text { cylinder } \\
\text { ROTAX } 74 \text { cid }\end{array}$ & 2 stages $/ \mathrm{TMS}$ & $\begin{array}{l}103 \mathrm{hp} \\
\text { at } 54 \mathrm{kft} \\
\text { Jan. } 1996\end{array}$ & $\begin{array}{c}47 \mathrm{hp} \\
\text { at } 70 \mathrm{kft} \\
\text { Jan. } 1996\end{array}$ & Not flown yet \\
\hline $\begin{array}{l}\text { ERAST Alliance I } \\
\text { Proof of Concept } \\
\text { (P.O.C) }\end{array}$ & $\begin{array}{l}\text { Thermo } \\
\text { Mechanical } \\
\text { Systems } \\
\text { (TMS) }\end{array}$ & $\begin{array}{c}4 \text { cylinder } \\
\text { ROTAX } 74 \text { cid }\end{array}$ & 3 stages $/ \mathrm{TMS}$ & $\begin{array}{c}100 \mathrm{hp} \\
\text { at } 76 \mathrm{kft} \\
\text { Feb. } 1997\end{array}$ & $\begin{array}{c}85 \mathrm{hp} \\
\text { at } 85 \mathrm{ktt} \\
\text { Nov. } 1997\end{array}$ & Not flown yet \\
\hline
\end{tabular}


TABLE III.-TURBOJET VERSUS TURBOCHARGED IC ENGINE

\begin{tabular}{|c|c|c|c|c|}
\hline $\begin{array}{l}\text { Powerplant/Propulsion system } \\
\text { (inlet recovery }=1.0 \text { ) }\end{array}$ & $\begin{array}{l}\text { Uninstalled weight } \\
\text { including propeller }\end{array}$ & $\begin{array}{l}\text { Delivered } \\
\text { thrust }\end{array}$ & $\begin{array}{l}\text { Specific } \\
\text { weight }\end{array}$ & $\begin{array}{c}\text { Specific } \\
\text { consumption }\end{array}$ \\
\hline $\begin{array}{l}\text { At } 80 \mathrm{ktt} \\
\text { J97 turbojet at } M=0.83 \\
\text { J97 turbojet at } M=0.8 \\
\text { New turbojet at } 0.5<M<0.85 \\
\text { Strato } 2 C \text { ( } 3 \text { stage TCSI) at } M=0.5 \\
\text { 80K ERAST } 3 \text { stage TCSI at } M=0.4\end{array}$ & $\begin{array}{l}715 \mathrm{lbm} \\
715 \mathrm{lbm} \\
920 \mathrm{lbm} \\
2457 \mathrm{lbm} \\
587 \mathrm{lbm}\end{array}$ & $\begin{array}{c}184 \mathrm{lbf} \\
\text { flameout } \\
190 \mathrm{lbf} \\
360 \mathrm{lbf} \\
91 \mathrm{lbf} \\
\end{array}$ & $\begin{array}{l}3.9 \mathrm{lbm} / \mathrm{bf} \\
4.8 \mathrm{lbm} / \mathrm{bf} \\
6.8 \mathrm{lbm} / \mathrm{bf} \\
6.5 \mathrm{lbm} / \mathrm{lbf}\end{array}$ & $\begin{array}{c}1.3 \mathrm{lbm} / \mathrm{hr} \text { per } \mathrm{lbf} \\
0 .----1 \\
0.8 \mathrm{lbm} / \mathrm{hr} \text { per lbf } \\
0.44 \mathrm{lbm} / \mathrm{hr} \text { per lbf } \\
0.44 \mathrm{lbm} / \mathrm{hr} \text { per lbf }\end{array}$ \\
\hline $\begin{array}{l}\text { At } 90 \mathrm{kft} \\
\text { New turbojet at } 0.5<M<0.85 \\
90 \mathrm{~K} \text { ERAST } 3 \text { stage } \mathrm{TCSI} \text { at } \mathrm{M}=0.4\end{array}$ & $\begin{array}{l}920 \mathrm{lbm} \\
667 \mathrm{lbm}\end{array}$ & $\begin{array}{l}120 \mathrm{lbf} \\
90 \mathrm{lbf}\end{array}$ & $\begin{array}{l}7.7 \mathrm{lbm} / \mathrm{lbf} \\
7.4 \mathrm{lbm} / \mathrm{lbf}\end{array}$ & $\begin{array}{l}0.8 \mathrm{lbm} / \mathrm{hr} \text { per } \mathrm{lbf} \\
0.44 \mathrm{lbm} / \mathrm{hr} \text { per } \mathrm{lbf}\end{array}$ \\
\hline
\end{tabular}

TABLE IV.-TURBOCHARGED POWERPLANT WEIGHT BREAKDOWN COMPARISON OF "UNINSTALLED HARDWARE" NO PROPELLER

\begin{tabular}{|c|c|c|}
\hline & Rotax 914 & 3 stage turbocharged ROTAX \\
\hline Rated HP at altitude & $80 \mathrm{hp}$ at $12,000 \mathrm{ft}$ & $80 \mathrm{hp}$ at $85,000 \mathrm{ft}$ \\
\hline \multicolumn{3}{|c|}{ Weight breakdown } \\
\hline $\begin{array}{l}\text { Core engine wrignition and fuel systems, } \\
\text { induction, exhaust collector and } \\
\text { wastegate }\end{array}$ & weight $=145 \mathrm{lbm}$ & weight $=184 \mathrm{lbm}$ \\
\hline Turbochargers (no of units) & $\begin{array}{l}1 \text { TC unit }-7 \text { in. od } \\
\times \text { weight }=15 \mathrm{lbm}\end{array}$ & $\begin{array}{l}\text { LP unit-20 in. od } \\
\text { weight }=60 \mathrm{lbm} \\
\text { IP unit-13 in. od } \\
\text { weight }=30 \mathrm{lbm} \\
\text { HP unit-7 in. od } \\
\text { weight }=11 \mathrm{lbm}\end{array}$ \\
\hline Ducting and insulation & weight $=4 \mathrm{lbm}$ & weight $=72 \mathrm{lbm}$ \\
\hline Intercoolers & $\begin{array}{l}7 \times 5 \times 2 \mathrm{in} . \\
\text { weight }=4 \mathrm{lbm}\end{array}$ & $\begin{array}{l}\text { LP coolers: } 12 \times 56 \times 2-1 / 2 \mathrm{in} . \\
\text { weight }=2 \times 7.1 \mathrm{lbm} \\
\text { IP coolers: } 12 \times 69 \times 2-1 / 2 \mathrm{in} \text {. } \\
\text { weight }=2 \times 9.7 \mathrm{lbm} \\
\text { HP coolers: } 12 \times 39 \times 2-1 / 2 \mathrm{in} \text {. } \\
\text { weight }=2 \times 5.8 \mathrm{lbm}\end{array}$ \\
\hline Oil cooler & $\begin{array}{l}7 \times 3 \times 1-3 / 8 \mathrm{in} . \\
\text { dry weight }=5 \mathrm{lbm}\end{array}$ & $\begin{array}{l}\text { oil to coolant } \mathrm{HX}: 9 \times 9 \times 2 \text { in. } \\
\text { dry weight }=6.7 \mathrm{lbm}\end{array}$ \\
\hline Engine coolant radiator & $\begin{array}{l}8 \times 4 \times 1 \mathrm{ln} . \\
\text { dry weight }=7 \mathrm{lbm}\end{array}$ & $\begin{array}{l}42 \times 44 \times 3 / 4 \text { in. } \\
\text { dry weight }=13 \mathrm{lbm}\end{array}$ \\
\hline Gearbox & 1 speed, integral w/core engine & $\begin{array}{l}2 \text { speeds, } \\
55 \mathrm{lbm}\end{array}$ \\
\hline $\begin{array}{l}\text { Lube system include oil tank and } \\
\text { ancillaries }\end{array}$ & dry weight $=15 \mathrm{lbm}$ & dry weight $=25 \mathrm{lbm}$ \\
\hline Liquid coolant & weight $=5 \mathrm{lbm}$ & weight $=22 \mathrm{lbm}$ \\
\hline ôl & weight $=4 \mathrm{lbm}$ & weight $=18 \mathrm{lbm}$ \\
\hline Total weight & $204 \mathrm{lbm}$ & $543 \mathrm{lbm}$ \\
\hline
\end{tabular}




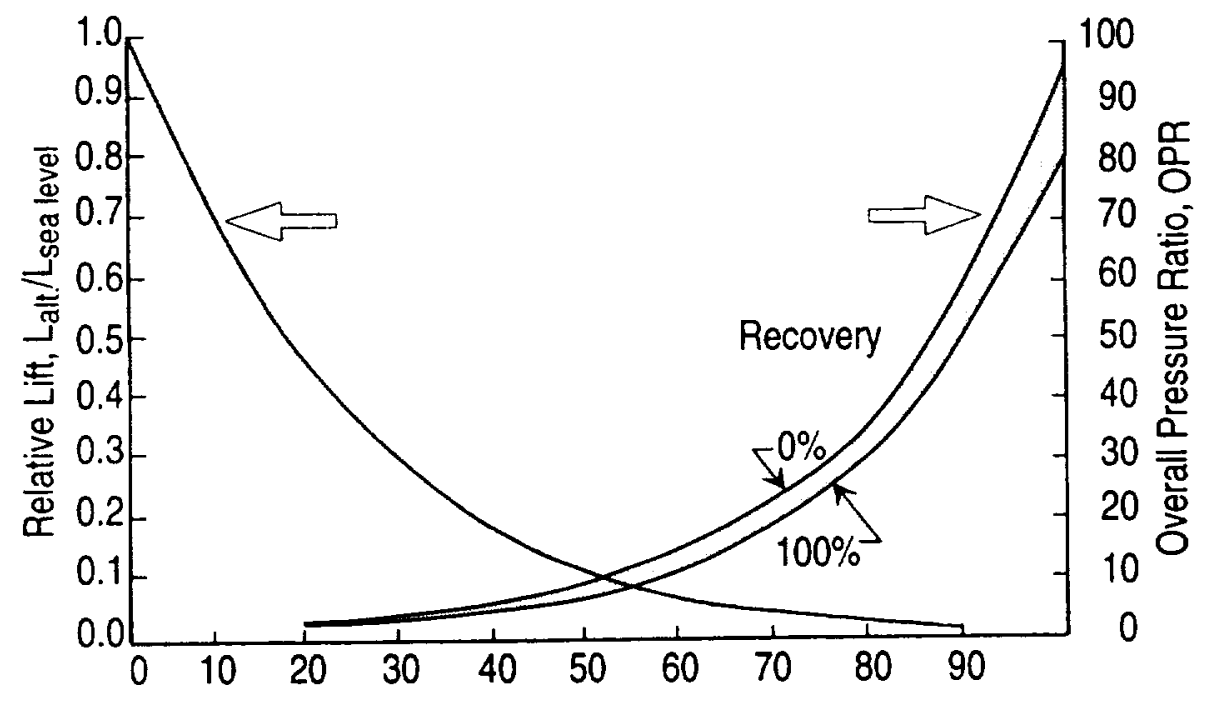

Altitude, ft. $\times 10^{-3}$

Figure 1.-Pressure ratio needed for flat-rated output power and relative wing lift versus altitude for constant flight Mach number of 0.50 . 
Sizing for altitude compensation (constant mass flow rate)

Axial Compressor

$10-100 \mathrm{lbm} / \mathrm{sec}$

(pressurizes combustor to 40 psia)

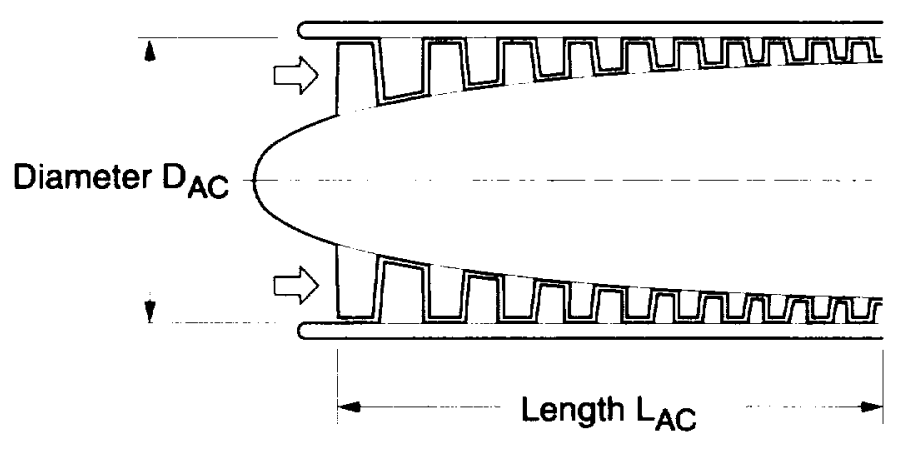

Centrifugal Compressor

$0.1-0.5 \mathrm{lbm} / \mathrm{sec}$

(pressurizes engine intake

manifold to 30 in $\mathrm{Hga}$ )

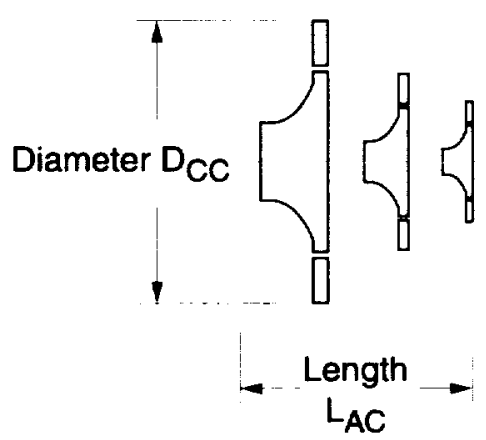

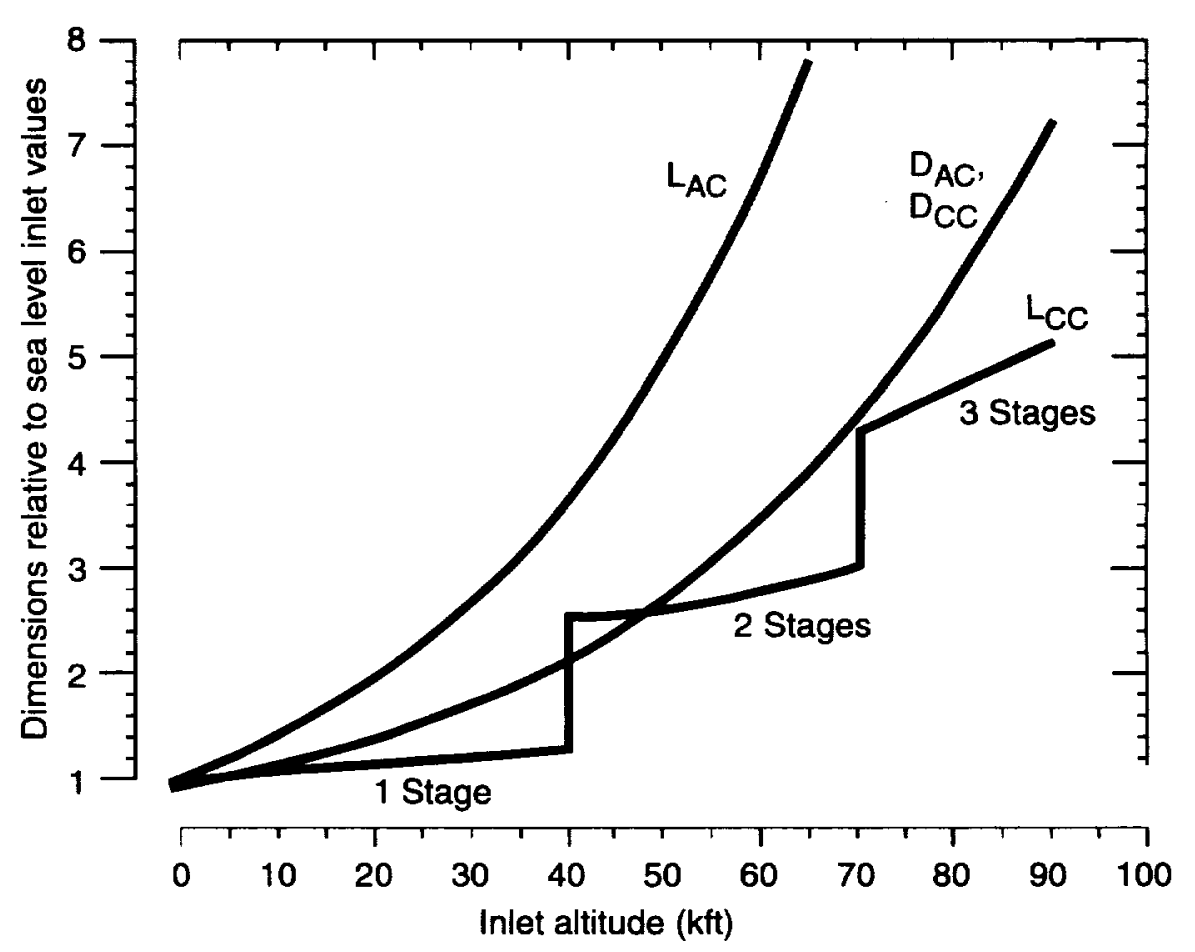

Figure 2.-Turbocompressor size variation with altitude. 


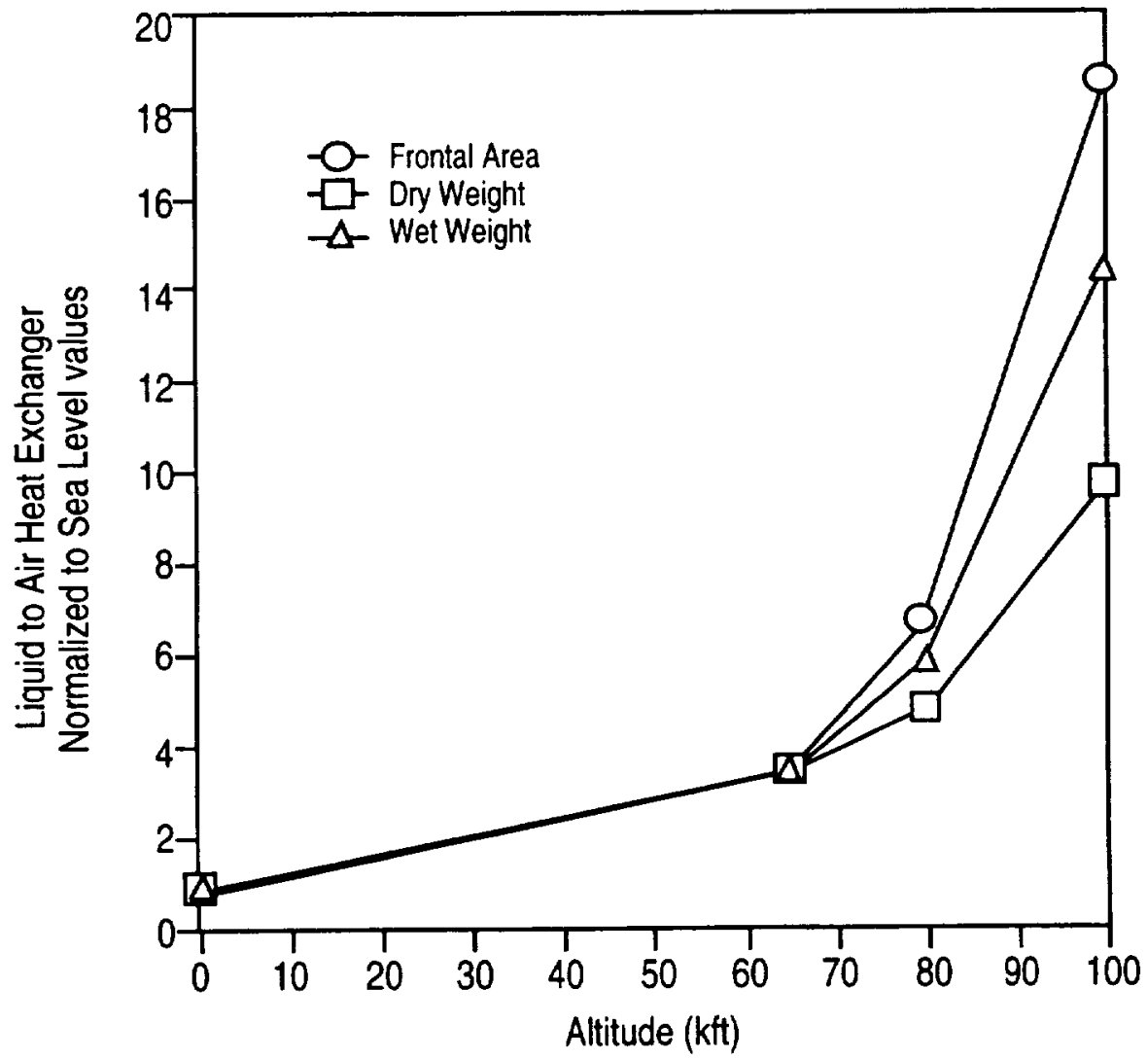

Figure 3.-Heat exchanger size variation with altitude.

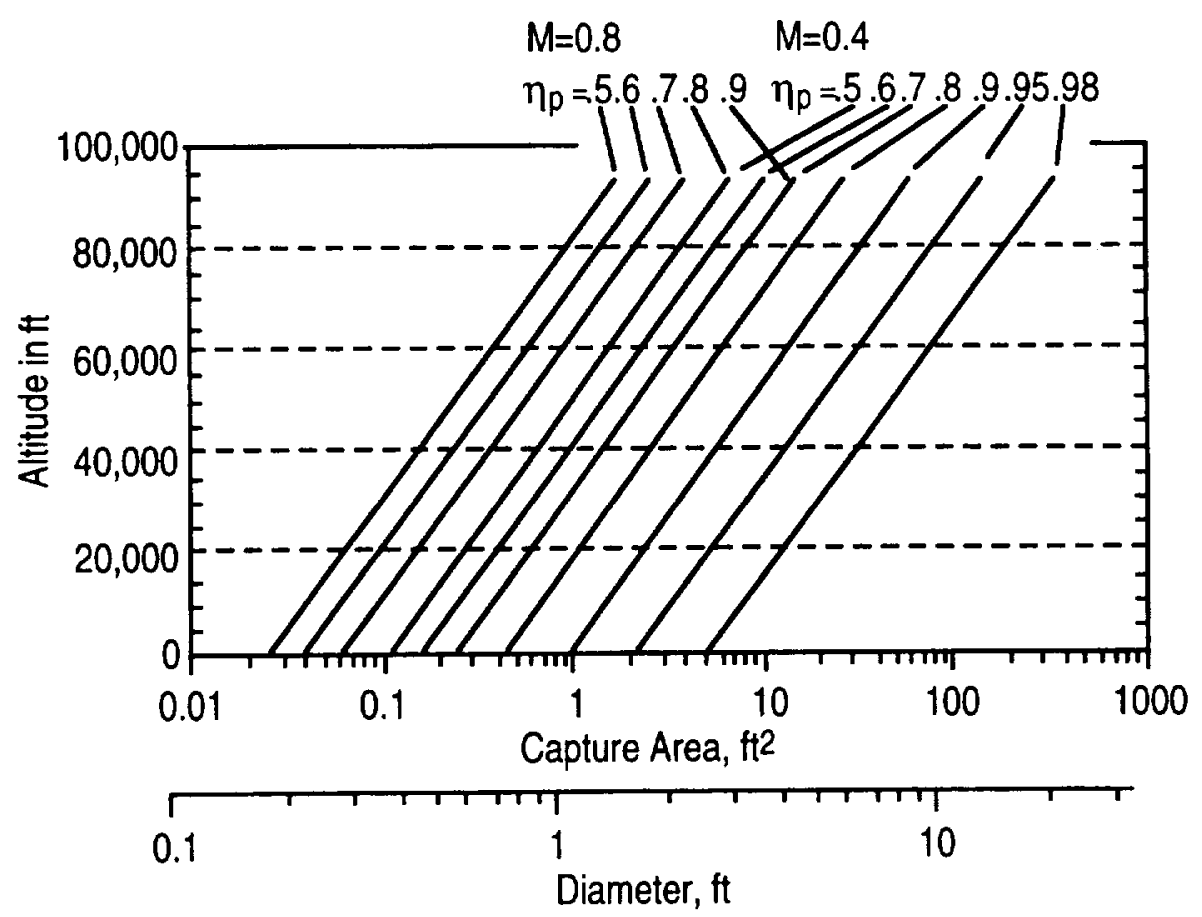

Figure 4.-Approximate capture area and diameter required for $100 \mathrm{lbf}$ thrust versus altitude, airspeed and desired propulsive efficiency. 


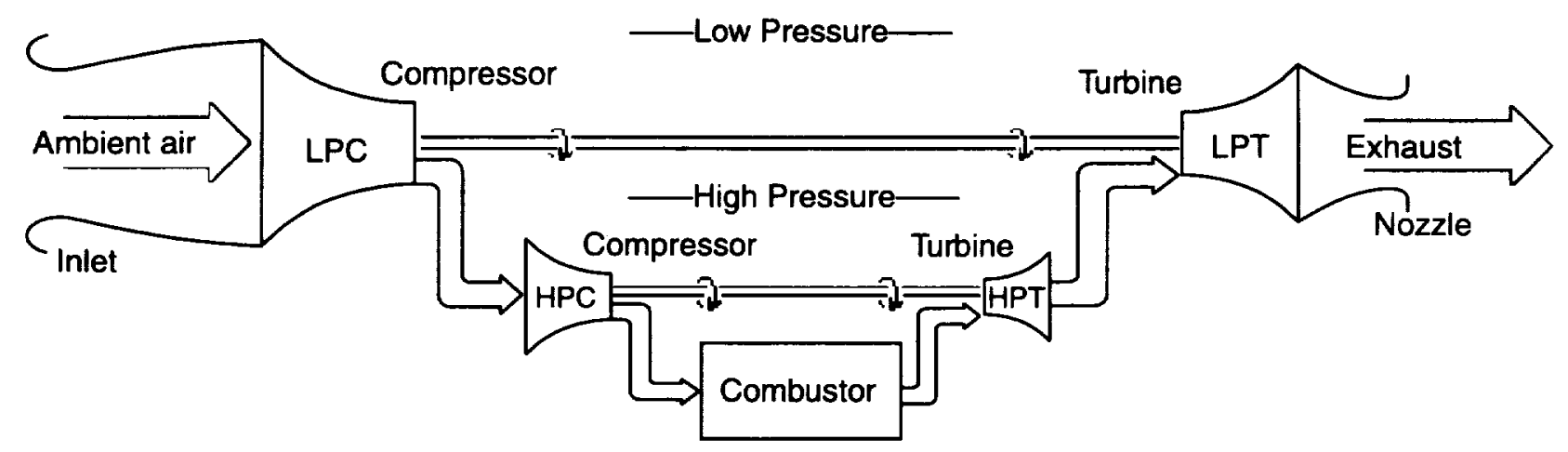

Figure 5.-High altitude turbojet.

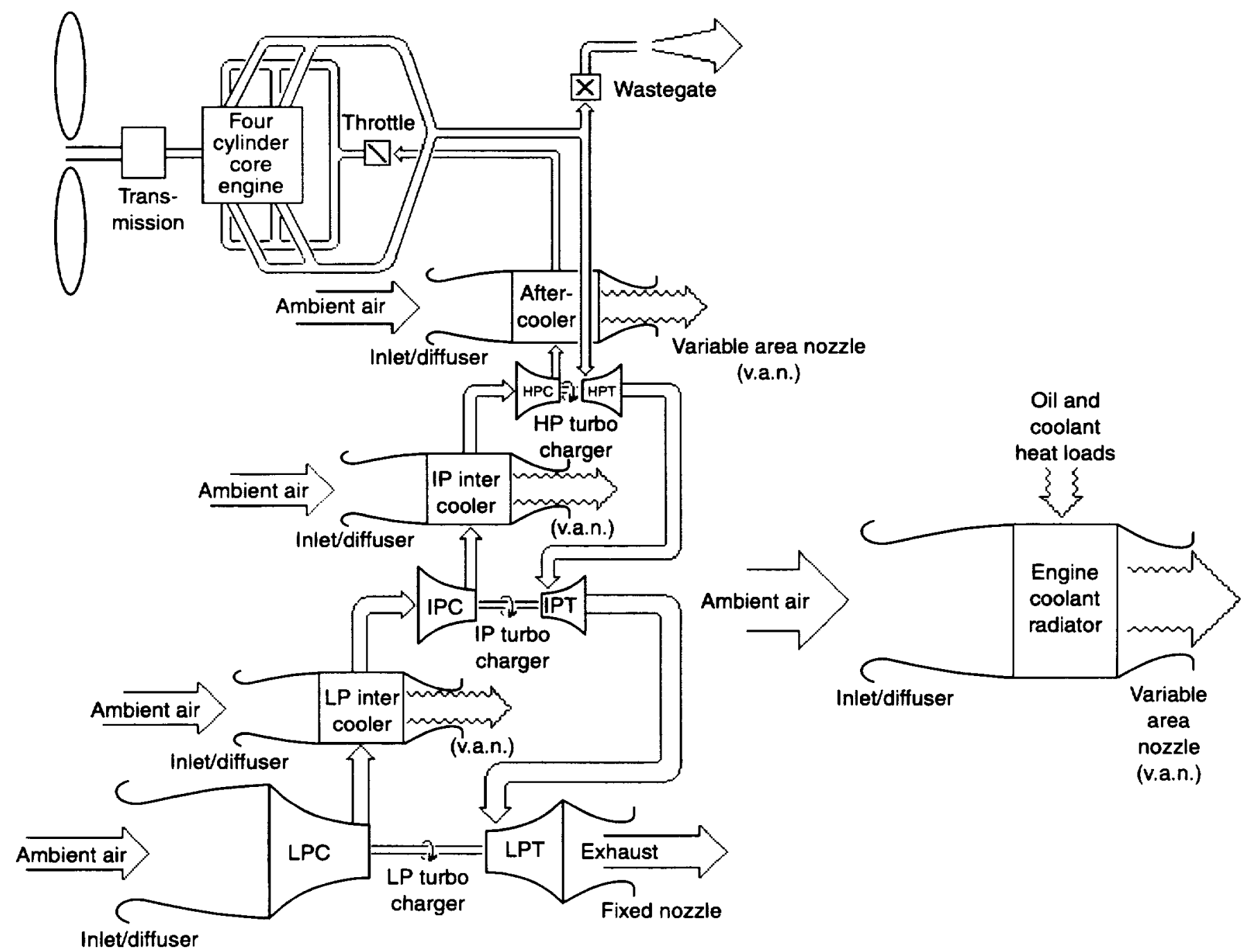

Figure 6.-Three Stage Turbocharged Powerplant. 


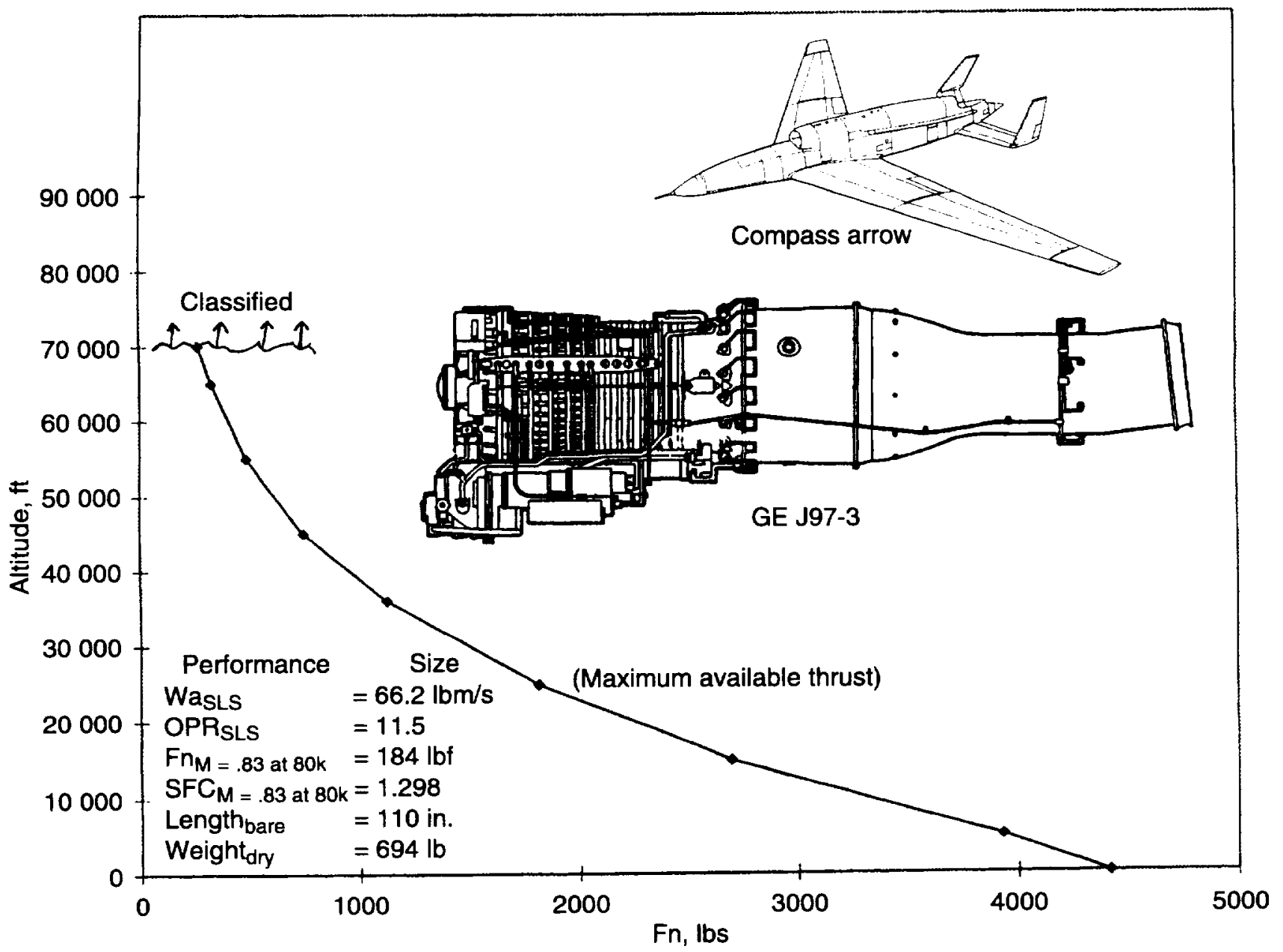

Figure 7.-"Compass arrow" high altitude turbojet (1966-72), thrust versus altitude. 


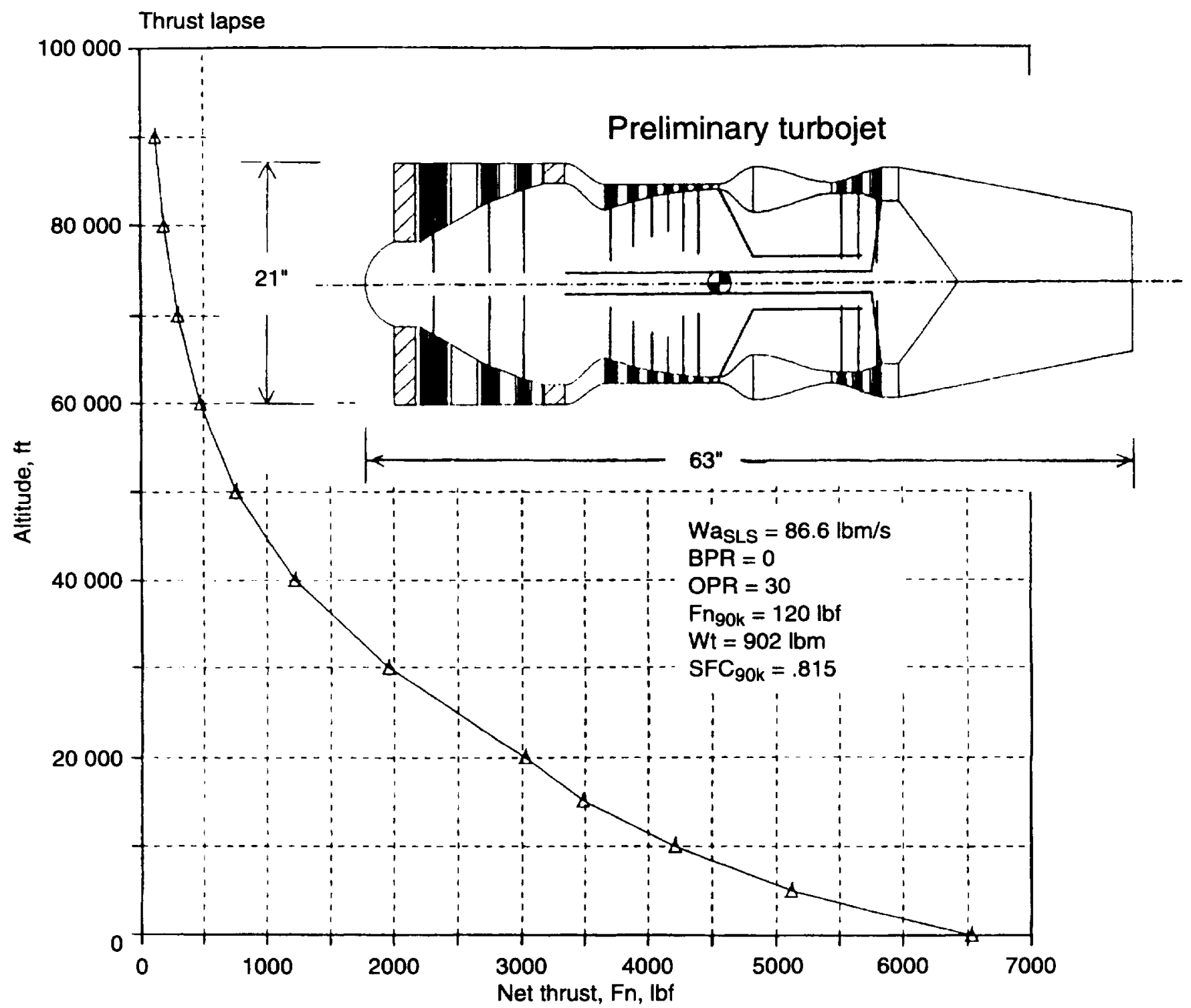

Figure 8.-New high altitude turbojet, thrust versus altitude. 


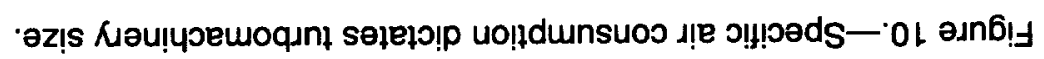

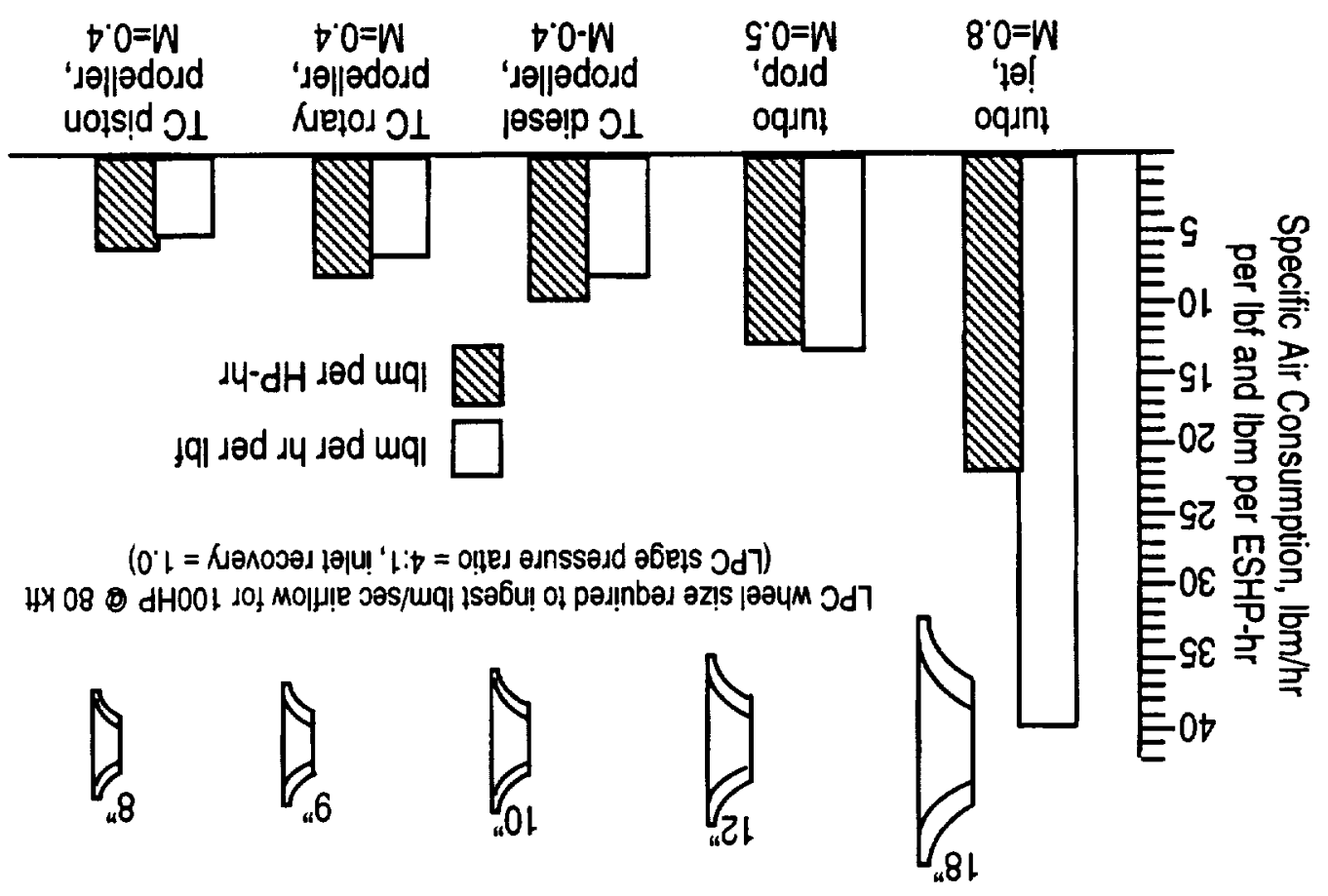

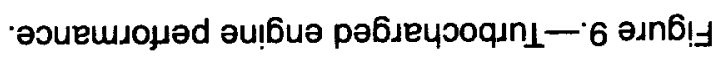

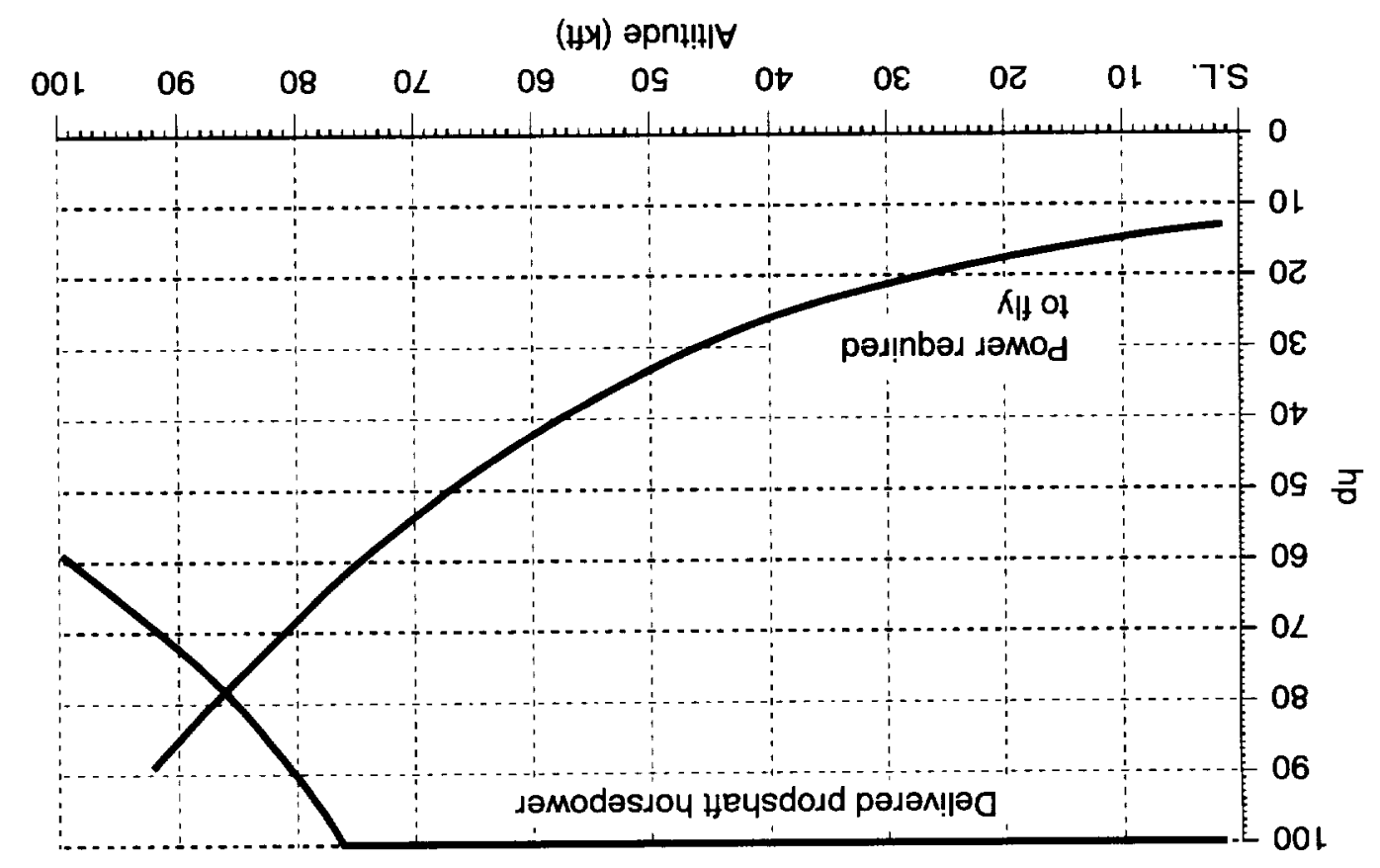




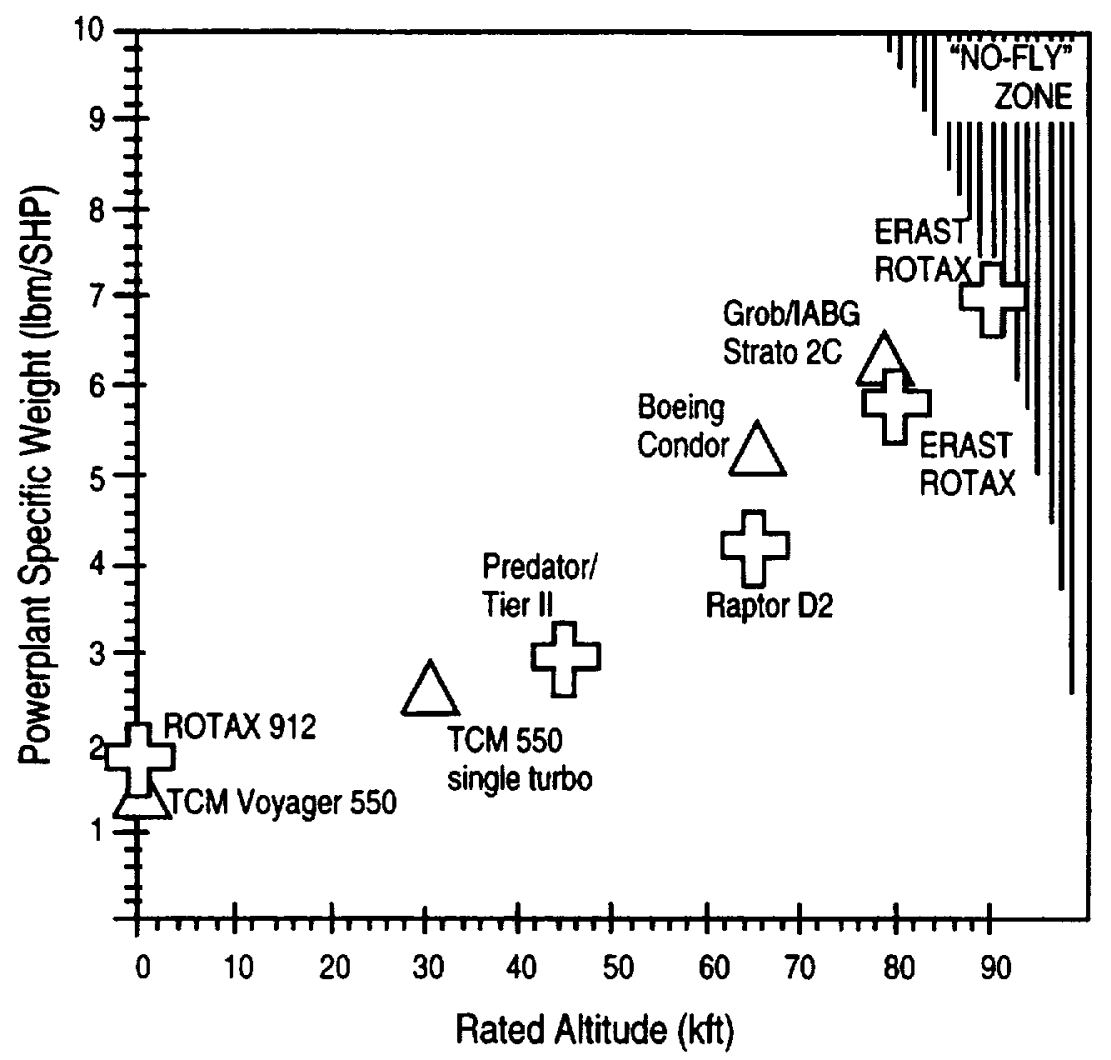

Figure 11.-Turbocharged powerplant growth trend with altitude.

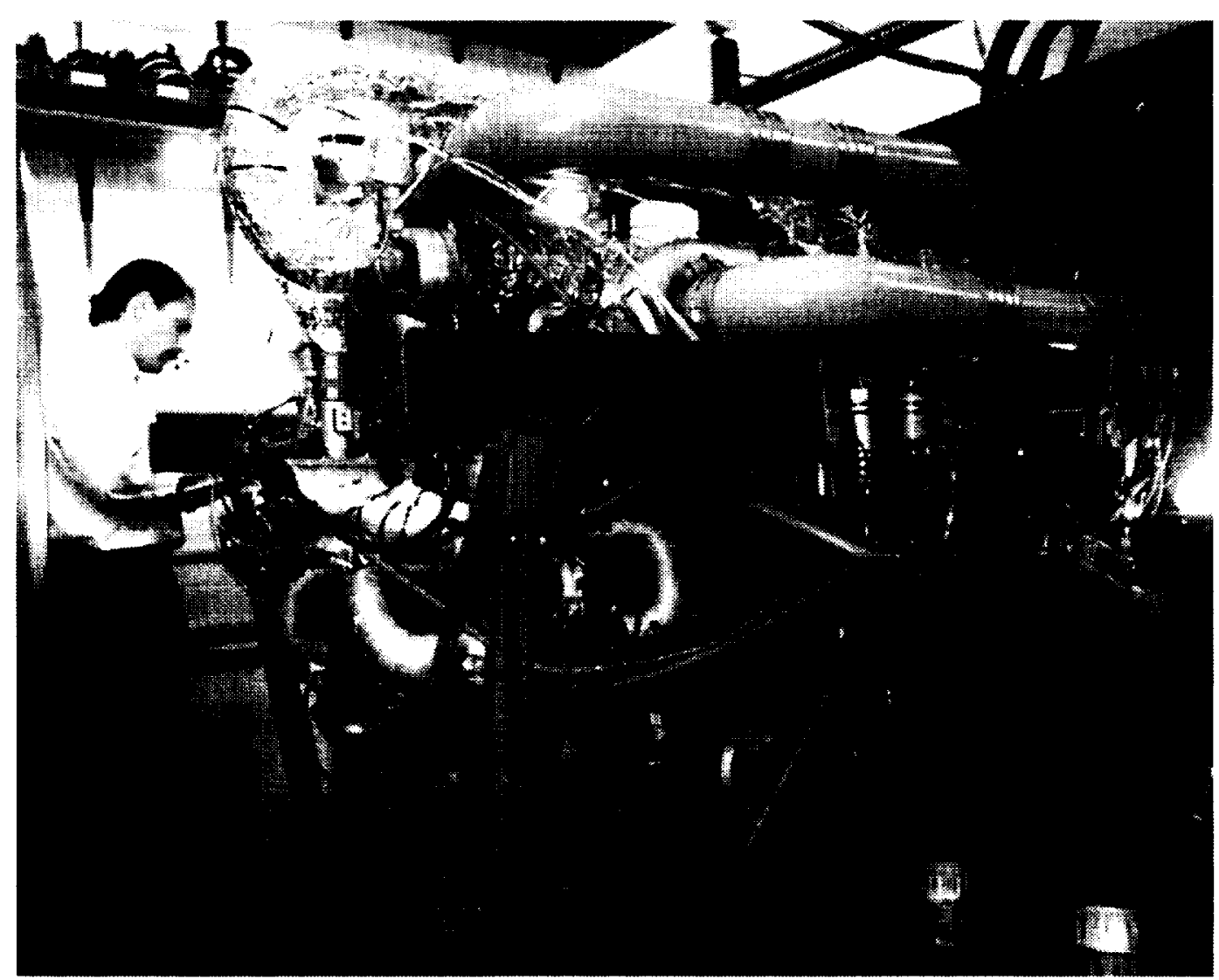

Figure 12.-TMS triply turbocharged Rotax engine. 


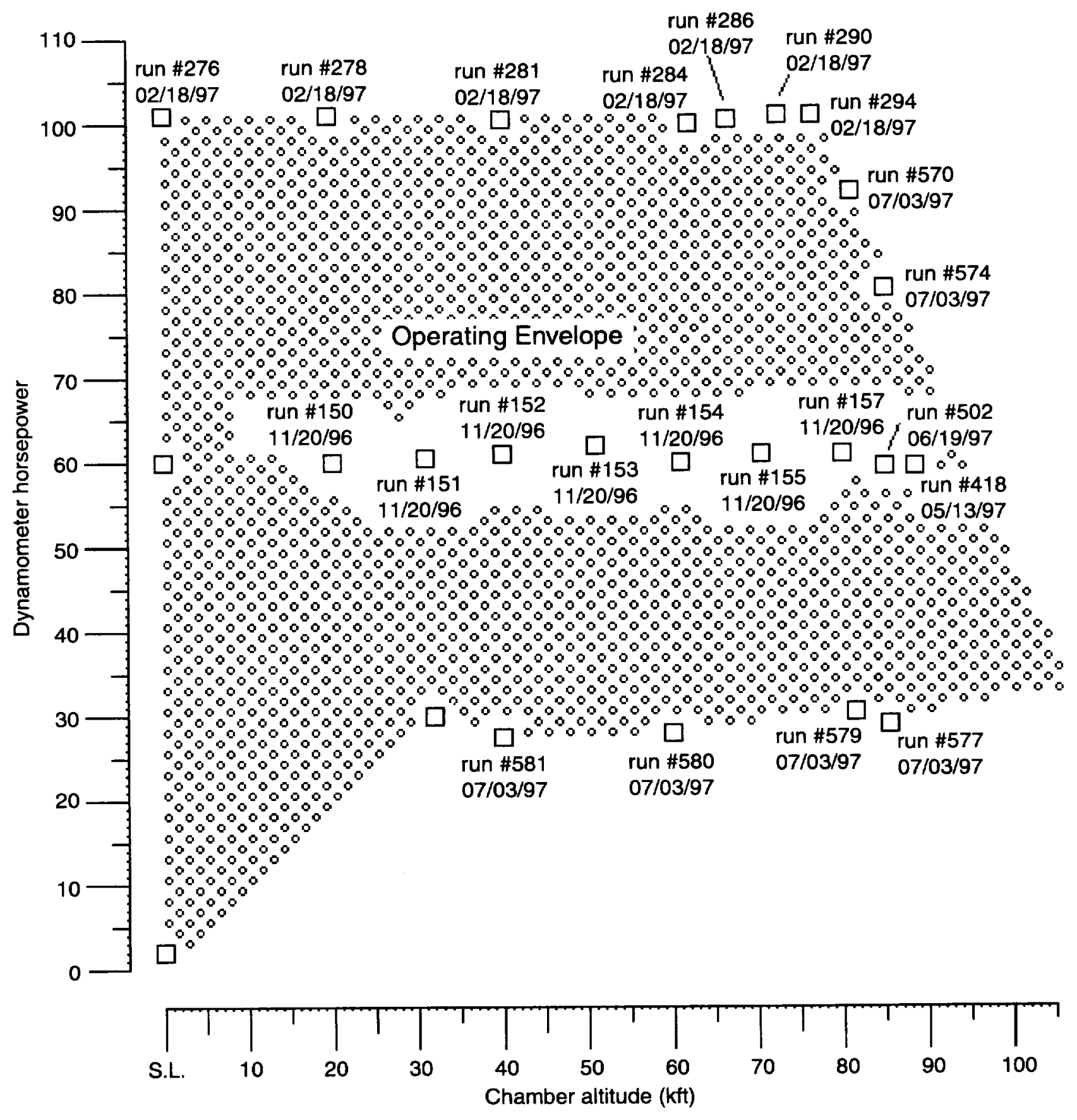

Figure 13.-TMS three stage turbocharged engine performance demonstration. 
Public reporting burden for this collection of information is estimated to average 1 hour per response, including the time for reviewing instructions, searching existing data sources, gathering and maintaining the data needed, and completing and reviewing the collection of information. Send comments regarding this burden estimate or any other aspect of this

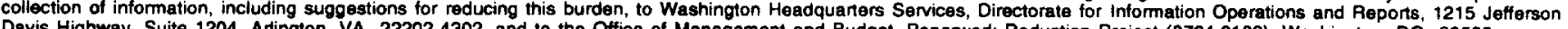
Davis Highway, Suite 1204, Arlington, VA 22202-4302, and to the Office of Management and Budget, Papenwork Reduction Project (0704-0189), Washington, DC 20503.

\section{\begin{tabular}{l|l} 
1. AGENCY USE ONLY (Leave blank) & 2. REPORT DATE
\end{tabular} \\ 3. REPOAT TYPE AND DATES COVERED}

4. TITLE AND SUBTTTLE

April 1998

Technical Memorandum

Propulsion System for Very High Altitude Subsonic Unmanner Aircraft

6. AUTHOR(S)

WU-529-10-13-00

David J. Bents, Ted Mockler, Jaime Maldonado, James L. Harp, Jr., Joseph F. King, and Paul C. Schmitz

\section{PERFORMING ORGANIZATION NAME(S) AND ADDRESS(ES)}

National Aeronautics and Space Administration

Lewis Research Center

Cleveland, Ohio 44135-3191

8. PERFORMING ORGANIZATION REPORT NUMBER

E-11101

9. SPONSORINGMONITORING AGENCY NAME(S) AND ADDRESS(ES)

10. SPONSORINGMONITORING AGENCY REPORT NUMBER

National Aeronautics and Space Administration

Washington, DC 20546-0001

NASA TM-1998-206636

11. SUPPLEMENTARY NOTES

Prepared for the Aerospace Power Systems ' 98 sponsored by the Society of Automotive Engines, Williamsburg, Virginia, April 21-23, 1998. David J. Bents, Ted Mockler, and Jaime Maldonado, NASA Lewis Research Center; James L. Harp, Jr. and Joseph F. King, ThermoMechanical Systems Inc., Canoga Park, California; Paul C. Schmitz, Power Computing Solutions Inc., Avon, Ohio. Responsible person, David J. Bents, organization code 5440, (216) 433-6135.

\begin{tabular}{|l|l|} 
12a. DISTRIBUTION/AVAILABILTY STATEMENT & 12b. DISTRIBUTION CODE
\end{tabular}

Unclassified - Unlimited

Subject Category: 07

Distribution: Nonstandard

This publication is available from the NASA Center for AeroSpace Information, (301) 621-0390.

13. ABSTRACT (Maximum 200 words)

This paper explains why a spark ignited gasoline engine, intake pressurized with three cascaded stages of turbocharging, was selected to power NASA's contemplated next generation of high altitude atmospheric science aircraft. Beginning with the most urgent science needs (the atmospheric sampling mission) and tracing through the mission requirements which dictate the unique flight regime in which this aircraft has to operate (subsonic flight @ $>80 \mathrm{kft}$ ) we briefly explore the physical problems and constraints, the available technology options and the cost drivers associated with developing a viable propulsion system for this highly specialized aircraft. The paper presents the two available options (the turbojet and the turbocharged spark ignited engine) which are discussed and compared in the context of the flight regime. We then show how the unique nature of the sampling mission, coupled with the economic considerations pursuant to aero engine development, point to the spark ignited engine as the only cost effective solution available. Surprisingly, this solution compares favorably with the turbojet in the flight regime of interest. Finally, some remarks are made about NASA's present state of development, and future plans to flight demonstrate the three stage turbocharged powerplant.

\section{SUBJECT TERMS}

High altitude; Air breathing propulsion; Turbine engines; Reciprocating engines

17. SECURTY CLASSIFICATION
OF REPORT
Unclassified

NSN 7540-01-280-5500

\begin{tabular}{|c|c|}
$\begin{array}{c}\text { 18. SECURITY CLASSIFICATION } \\
\text { OF THIS PAGE } \\
\text { Unclassified }\end{array}$ & $\begin{array}{c}\text { 19. SECURITY CLASSIFICATION } \\
\text { OF ABSTRACT } \\
\text { Unclassified }\end{array}$ \\
\hline
\end{tabular}

Standard Form 298 (Rev. 2-89) Prescribed by ANSI Std. Z39-18 298-102 